\title{
Stunting and development of behavior
}

\author{
Verawati Simamora, Sabar Santoso, Nanik Setiyawati
}

Midwifery Department, Poltekkes Kemenkes Yogyakarta, Indonesia

\begin{tabular}{l} 
Article Info \\
\hline Article history: \\
Received Aug 28, 2019 \\
Revised Nov 15, 2019 \\
Accepted Nov 28, 2019 \\
\hline
\end{tabular}

\section{Keywords:}

Development

Stunting

Toddlers

\begin{abstract}
The current study aimed to examine the relationship between the incidence of Stunting, characteristics of mother with the development of toddlers 24-59 months in the work area of Sentolo I Public Health Center, KulonProgo Regency. The study design used was a retrospective cohort (historical cohort). The research was conducted in May 2019. The population of this study was all under-fives under the Sentolo Health Center I work area. There were 130 respondents consisting of 65 exposed groups and 65 unexposed groups participated in this study. The analysis used in this study used Chi-square.Developments wasdetected using Denver II. The results of the bivariate analysis showed that there was a relationship betweenStunting and the development of toddlers 24-59 months $(p=0.003$ ). There was no relationship between sex and number of siblings with the development of children under five $(p=0.808)$. There is a significant relationship between the level of knowledge of mothers and toddler development $(\mathrm{p}=0.859)$. There is a relationship between the level of education of mothers with development $(\mathrm{p}=0.003)$. There is a relationship between family income and the development of $(\mathrm{p}=0.001)$, but there is no relationship between the work of mothers and children under five years $(\mathrm{p}=0.001)$. There is a relationship between Stunting and developing toddlers 24-59 months in the working area of Sentolo I Public Health Center, KulonProgo Regency.
\end{abstract}

Copyright $@ 2019$ Institute of Advanced Engineering and Science. All rights reserved.

\section{Corresponding Author:}

Nanik Setiyawati,

Midwifery Department of Poltekkes Kemenkes Yogyakarta,

Jl.Mangkuyudan MJ III/304, Yogyakarta, 55143, Indonesia.

Email: nanikyogya@gmail.com

\section{INTRODUCTION}

There are three health problems that become Government programs, namely TB, Stunting and Immunization. Stunting is stunted growth (Growing Short) [1]. Stunting occurs due to failure during child development because health conditions and nutritional intake are not optimal. Stunting is often associated with socio-economic conditions, presenting several diseases and nutritional intake that lack quality and excess [2]. Stunting is a place where the tall body is shorter than the height body of others in general (as appropriate). Children experience greater growth to become adults who are less educated, poor, unhealthy and vulnerable to non-communicable diseases [3].

Stunting is a condition in which a person's height is shorter than other people's height in general (as appropriate). Stunting occurs because the lack of nutritional intake received by the fetus/infant malnourished occurs since the baby is in the womb and at the beginning of the child's birth. According to Minister of Health Decree number 1995/KEMKES/SK/XII/2010 concerning anthropometric standards Ranking of nutritional status of children in accordance with the Body Length Index according to Age (PB/U) or Body Height by Age $(\mathrm{TB} / \mathrm{U})$. Stunting toddlers can be known if a toddler has measured his length or height, then compared to the standard and the results are below normal. Short toddlers are toddlers with 
nutritional status based on length or height according to age when compared to the standard WHO-MGRS (Multicentre Growth Reference study) in 2015, the z-score is less than-2SD [4].

The Stunting prevalence in Indonesia in 2013 was $37 \%$ but in 2018 it fell to $30.8 \%$ where the WHO limit was $<20 \%$ so Stunting was included in the health problems in Indonesia. This means that not optimal growth is experienced by around 8.9 million children in Indonesia or 1 in 3 children in Indonesia experiencing Stunting where children who are stunted on average occur under the age of 5 years. The prevalence of short-term babies in DIY in 2015 was $14.86 \%$, down in 2016 to $11 \%$ and again increasing in 2017 to $13.86 \%$ [5].

Development is an increase in ability in terms of structure and function of the body that is more complex. Development has a regular pattern and can be predicted which is the result of the maturation process. The term development refers to the function of an organ or individual while growth (Growth) is a major change in terms of number and size at the level of organ cells and individuals or can be said to be a physical impact [6] in the first year. In 2010 the disruption of child growth and development in Indonesia reached 35\%. This figure exceeds the World Health Organization (WHO) limit of 30\% [7].

According to WHO 2013, Stunting can affect motor, cognitive, personal, social and language development which are short-term consequences for toddler development so that if not resolved can lead to long-term consequences namely health, development and economic problems [8]. The purpose of this study was to find out the stunting relationship with the development of toddlers 24-59 months. Knowing the relationship of characteristics to toddler development included toddler sex, number of siblings, level of mother's knowledge, maternal education level, maternal occupation and family income on toddler development.

The benefits of this study are to provide benefits and add insight into Stunting Relationship with the development of toddlers 24-59 months. For Sentolo I Health Centers The results of this study were used as input for Puskesmas in Stunting and development services for toddlers. For midwives and child health practitioners (KIA) it is hoped that the results of the research can be input and information to prevent abnormal development. For the next researcher, it is expected to be able to add information for the basis and reference of research by further research that will conduct research related to the development of toddlers.

\section{METHOD}

The type of research carried out is a type of observational analytic (non-experimental) research. The study design used was a retrospective cohort (historical cohort). The design was chosen because it is a good design in assessing the relationship between risk factors and their effects [9]. The population of this study were all toddlers in 2017 in the work area of Sentolo I Health Center in KulonProgo Regency with 1,572 toddlers. The sampling technique was done by purposive sampling, by making inclusion and exclusion criteria. The sample size was 130 toddlers. This research was approved by Health Research Ethics Commission (KEPK) Health Polytechnic of the Ministry of Health Yogyakarta on May 21, 2019 with No.e_KEPK/POLTEKESYO/0081/V/2019.

\section{RESULTS AND DISCUSSION}

Data is gathered from 130 respondents, divided into two groups, namely $50 \%$ of groups exposed and $50 \%$ of groups not exposed. Female sex $56.2 \%$ more than male sex $43.8 \%$. In the number of siblings there were $74.6 \%$ having siblings and $25.4 \%$ toddlers who did not have relatives. At the level of maternal education there are more mothers with high school education levels of $54.6 \%$ while for mothers with elementary, junior high school level $43.1 \%$ and mothers with tertiary education level of $2.3 \%$. At work $70 \%$ of mothers do not work and $30 \%$ are working mothers. For the level of knowledge of $48.5 \%$ of mothers with sufficient knowledge, $39.2 \%$ of mothers with good knowledge and $12.3 \%$ of mothers with less knowledge. Family income is majority low income (65.4\%).

\subsection{Relationship characteristics with development}

Characteristic relationship to the development of children under five is presented in the following table. Table 1 shows that there is no sex relationship with the development of toddlers p-value 0.808 . The table shows that there is no relationship between the number of siblings and the development of children under five years p-value 0.859. At the maternal education level there is a relationship with the development of children under five p-value 0.003. In the mother's work there is no relationship between the work of the mother and the development of the toddler p-value 0.871. At the level of maternal knowledge there is a relationship between the level of knowledge of mothers with the development of toddlers p-value 0.000. In family income there is a relationship between family income and the development of children under five p-value 0.001 .

Int. J. Public Health Sci. Vol. 8, No. 4, December 2019: 427 - 431 
Table 1. Characteristic relationships with development

\begin{tabular}{|c|c|c|c|c|c|}
\hline \multirow{3}{*}{ Independent variable } & \multicolumn{4}{|c|}{ Development } & \multirow{3}{*}{ p-value } \\
\hline & \multicolumn{2}{|c|}{ Abnormal } & \multicolumn{2}{|c|}{ Normal } & \\
\hline & $\mathrm{f}$ & $\%$ & $\mathrm{f}$ & $\%$ & \\
\hline \multicolumn{6}{|l|}{ Child sex } \\
\hline man & 20 & 46.5 & 37 & 42.5 & 0.808 \\
\hline women & 23 & 53.5 & 50 & 57.5 & \\
\hline Total & 43 & 100 & 87 & 100 & \\
\hline \multicolumn{6}{|l|}{ Number of siblings } \\
\hline There is no brother & 10 & 23.2 & 23 & 26.4 & 0.859 \\
\hline There are brothers & 33 & 76.8 & 64 & 73.6 & \\
\hline Total & 43 & 100 & 87 & 100 & \\
\hline \multicolumn{6}{|l|}{ Mother's education level } \\
\hline Elementary, Middle School/equivalent & 27 & 62.8 & 29 & 33.3 & 0.003 \\
\hline High school/equivalent & 16 & 37.2 & 55 & 63.2 & \\
\hline PT/equivalent & 0 & 0 & 3 & 3.5 & \\
\hline Total & 43 & 100 & 87 & 100 & \\
\hline \multicolumn{6}{|l|}{ Work } \\
\hline Does not work & 31 & 72.1 & 60 & 68.9 & 0.871 \\
\hline Work & 12 & 27.9 & 27 & 31.1 & \\
\hline Total & 43 & 100 & 87 & 100 & \\
\hline \multicolumn{6}{|l|}{ Level of mother's knowledge } \\
\hline Less & 9 & 21 & 7 & 8 & 0.000 \\
\hline Enough & 27 & 62.8 & 36 & 41.4 & \\
\hline Well & 7 & 16.2 & 44 & 50.6 & \\
\hline Total & 43 & 100 & 87 & 100 & \\
\hline \multicolumn{6}{|l|}{ Family income } \\
\hline Less than UMK & 37 & 86 & 48 & 55.2 & 0.001 \\
\hline More similar to the UMK & 6 & 14 & 39 & 44.8 & \\
\hline Total & 43 & 100 & 47 & 100 & \\
\hline
\end{tabular}

\subsection{Stunting relationship with toddler development}

This research found that shows of 65 stunting toddlers there were $69.7 \%$ of toddlers who had developmental problems and $40.2 \%$ had normal development, while 65 under-fives were not Stunting who had developmental disorders as much as $30.3 \%$ and $59.8 \%$ of toddlers not experiencing development problems. The Chi-square test results are $p$-value 0.003 which means there is a relationship between Stunting and the development of toddlers 24-59 months.

Toddlers are short (stunted) and very short (severely stunted) are toddlers with body length (PB/U) or height $(\mathrm{TB} / \mathrm{U})$ according to their age compared to the standard WHO-MGRS (Multicentre Growth Reference Study) 2006. Whereas the definition of Stunting according to the Ministry of Health (Kemenkes) are toddlers with a score of $\mathrm{z}$-score less than-2SD/standard deviation (stunted) and less than-3SD (severely stunted) [10]. One indicator of the nutritional status of a baby born is the body length at birth besides weight at birth. The length of a baby is considered normal between $48-52 \mathrm{~cm}$. So the birth length $<48$ $\mathrm{cm}$ is classified as a short baby. But if we want to link body length to birth with the risk of getting non-communicable diseases later in life, WHO recommends a limit value $<50 \mathrm{~cm}$ [11].

This research was conducted in May at several posyandu in the Sentolo I Health Center in KulonProgo Regency by looking at the MCH handbook and direct development checks using Denver II and mother's knowledge about development. The results of this study indicate that there is a Stunting relationship with the development of toddlers 24-59 months with p-value 0.003 . In this study it was found that Stunting toddlers $69.7 \%$ experienced developmental disorders. Stunting affects the development of toddlers because it has long-term effects on health performance. In this study it was found that there was a Stunting relationship to the development of toddlers, namely with a p-value of $0.003<0.005$. This study is in accordance with the research conducted by Hanani 2016 in Jangli Semarang Village. The results showed that the Stunting had an effect on gross motoric development, fine motoric, language and social personal children. Data collected included data on subject characteristics, maternal characteristics, nutritional status, and child development. Nutritional status was measured by comparing height with age, and data on child development was measured by questionnaire Development Pre-Screening (KPSP) [12].

Children under 5 years in developing countries are exposed to various risks, including poverty, malnutrition, poor health, and an unstimulating home environment, which affects their cognitive, motor and social-emotional development. There are several national statistics on the development of children in developing countries. We therefore identified two factors with data available throughout the world the prevalence of early childhood Stunting and the number of people living in absolute poverty-to be used as indicators of poor development. Show that both indicators are closely related to poor cognitive and educational performance in children and use them to estimate that more than 200 million children under 
5 years do not fulfill their development potential. Children who are severely malnourished tend to perform poorly in school and then to low income, high fertility, and provide poor care for their children, thus contributing to intergenerational poverty transmission [13].

Increase in height over 2 years is significantly related to changes in mental age, and the value of movement and hearing and the scale of speech subscale. Height increase in the first year is predicted to change in mental age, and hearing and speaking in the second year. Some of the effects of supplementation on development are divided by linear growth. Therefore, nutrition might explain part of the relationship between growth and development. However, supplementation also has an effect on development that is not dependent on growth. The benefits of supplementation on development and the extent to which they are shared with growth vary between subscales [14].

Toddler sex and number of siblings are several family factors and customs in the family that influence development, gender and number of siblings are biological factors that can influence development but in this study we get results that gender and number of siblings are not related to development with p-value $0.808>0.005$ and $0.859>0.005$. The results of this study are not in accordance with Soetjahningsih's theory that family factors and customs that affect development include gender and number of siblings. Children of male sex are often sick compared to women but it is not known exactly what causes them. The number of children that have a lot of influence on the development of toddlers with sufficient socio-economic conditions will result in a lack of love and attention to children while in the economy it will also result in a lack of primary needs such as food, clothing and housing not met [15].

The mother's level of education and mother's knowledge influence development because mothers with good knowledge know more about how to stimulate or stimulate toddlers so that their development is in accordance with their age. In this study found the results that maternal education has an effect on development with p-value 0.003 and maternal knowledge influences development with p-value 0.001 . This is in accordance with the study Hastuti, that mother's knowledge and mother's level of education is an important role in stimulating the potential of children. Parenting tasks are generally left to the mother based on the knowledge she has. One of the factors that influence knowledge is the education level of the mother. If mothers have high knowledge, they will be more active in seeking information to improve skills in childcare [16].

Mother's work affects the development of children under five because working mothers are expected to be better able to meet the needs of toddlers from the economy. In this study there was no relationship between working mothers and the development of children with p-value $0.871>0.005$. This research is not in accordance with the Soetjaningsih Theory of the Family who works will support the development of toddlers because parents will provide all the needs of children both primary and secondary. According to Act No. 13 of 2013, employees who work 7 hours per day for 6 days of work, so that working mothers still have time to provide stimulation, love and affection, the quality of parent interaction to children [15, 17]

Family income influences the development of toddlers because it is expected that families who earn more than UMK are expected to be able to meet the nutritional needs of children under five, so that good toddler nutrition does not affect the development of toddlers. In this study it was found that there was a relationship between family income and the development of toddlers with p-value 0.001 . This study is in accordance with Ozkan's research which states that socio-economic has a large influence on the development of children up to the age of five years, in this study the abnormal results of the denver test showed a high number, one of which was due to low parental education in which these factors would be related with low household income [18].

Stunting in children under five is a consequence of several factors often associated with poverty including nutrition, health, sanitation and the environment. There are five main factors causing Stunting, namely poverty, social and culture, increased exposure to infectious diseases, food insecurity and public access to health services. Factors related to chronic nutritional status in children under five are not the same between urban and rural areas, so the response efforts must be adjusted to the factors that influence. Stunting is a major nutritional problem that will have an impact on social and economic life in society. Stunting toddlers tend to have difficulty achieving optimal growth and development potential both physically and psychomotor [19] Stunting children impairment rate increased with age reaching 21\% in three years children [20]. Given that nearly $40 \%$ of children under age five suffer from loss of developmental potential-for which stunting is likely one of the key risk factors-reductions in stunting could have tremendous implications for child development [21]. Suggestionthe benefits of this research areFor Sentolo I Health Centers The results of this study are expected to be used as input for Puskesmas in Stunting and development services for children under five so as to reduce Stunting and developmental problems in the Sentolo I Health Center in KulonProgo Regency. For Midwives and Child Mother Health Practitioners (MCH) The results of this study are expected to be used as information material in making activities in an effort to improve the nutritional status of infants and encourage the implementation of prevention efforts or eliminate 
the possibility of developing developmental problems in infants. For Researchers Next Expand the research area so that the results obtained can be generalized. Add to other characteristics that might affect the development of toddlers.

\section{CONCLUSION}

The conclusion of this study showed that there are no relationship between sex, number of sibling, mothers' work with development ogf toddler. There are relationship between the level of knowledge of mother, level of educational of mother, family income, stunting with development of toddlers. Stunting has 2,3 more risk to development of toddles 24-59 months in Sentolo, Kulon Progo

\section{REFERENCES}

1. Ministry of Health Indonesia. Overcome health problem in three years. 2018. Available from: http://www.depkes.go.id/article/view/18030700005/rakerkesnas-2018-kemenkes-percepat-atasi-3-masalahkesehatan.html.

2. Unicef. Mother and Child Nutrition. Review summary. 2012. Available from: https://www.unicef.org/indonesia/id/A6_-_B_Ringkasan_Kajian_Gizi.pdf

3. WHO. 2014. Global Nutrition Target 2025. Stunting policy brief. Geneva. Available from: https:/www.who.int/nutrition/topics/globaltargets_stunting_policybrief.pdf.

4. Ministry of Health Indonesia. Infodatin Stunting toddler situation. Jakarta; 2016. Available from: http://www.depkes.go.id/resources/download/pusdatin/infodatin/situasi-balita-pendek-2016.pdf.

5. Yogyakarta's health profile. Information of Yogyakarta's profile. 2017. Available from: http://www.depkes.go.id/resources/download/profil/PROFILKES_PROVINSI_2017/14_DIY_2017.pdf.

6. WHO. 2011. WHO child growth standars. Geneva. Word Health Organinazation.Apps.who.ints/iris/bitstream/10665/43413/1/924154693X_eng.pdf.

7. Ministry of Health Indonesia. Information of Indonesia health profile 2017. Indonesian Ministry of Health; Jakarta 2018. Available from: http://www.depkes.go.id/resources/download/pusdatin/profil-kesehatan/Profil-KesehatanIndonesia-tahun-2017.pdf.

8. WHO. 2013. Childhood Stunting: Challenges and opportunities. Available from: https://apps.who.int/iris/bitstream/handle/10665/107026/WHO_NMH_NHD_GRS_14.1_eng.pdf;jsessionid=89D07 C3A25C0DBE9A1E8405BBF5DFB6F?sequence=1

9. Notoatmodjo Soekidjo. Heath Research Methodology. Jakarta: Rineka Cipta. 2014.

10. The National Team for Accelerating Poverty Reduction. 100 priority districts for stunting intervensions. Available from: http://www.tnp2k.go.id/images/uploads/downloads/Buku\%20Ringkasan\%20Stunting.pdf.

11. Unicef India. Stunting reflects chronic undernutrition during the most critical periods of growth and developmet in early life. Available from: Http://unicef.in/whatwedo/10/stunting.

12. Hanani. The effects of stunting to the development of gross motor, fine motor skills, language and social personal of Jangli village Semarang. Available from: https://media.neliti.com/media/publications/92844-ID-perbedaan perkembangan-motorik-kasar-mot.pdf.

13. Grantham all. Developmental potential in the first 5 years for children in developing countries.2007. Available from: https://reader.elsevier.com/reader/sd/pii/S0140673607600324?token=30966874011A596FF452834098FEFA4D350 FA5EE9C9FD7835CD0883C17950E91B0B14FBEC15E04CEEA21E11244B82C10

14. Powell All. Relationships between physical growth, mental development and nutritional supplementation in stunted children: the Jamaican study. 1995. Available from: https://onlinelibrary.wiley.com/doi/pdf/10.1111/j.16512227.1995.tb13479.x

15. Soetjahningsih. IG,N,Gde Ranuh. Child Development. EGC; 2016.

16. Hastuti D 2010. Child value, psychosocial stimulation, and cognitive development of children 2-5 years in foodinsecure families in Banjarnegara, Central Java, Journal of Health Sciences and Counseling. 3(1): 27-34. (28 Oktober 2018) journal.ipb.ac.id. Available from: http://journal.ipb.ac.id/index.php/jikk/article/view/5181

17. Republic of Indonesia Law Number 13 of 2013. Available from: http://www.kemenperin.go.id/kompetensi/UU_13_2003.pdf

18. Ozkan, M., Senel, S., Arslan, E. A. \&Karacan, C. D. The socioeconomic and biological risk factors for developmental delay in early childhood. European Journal of Pediatrics.;171(12): 1815-1821. 2012. Available from:https://www.researchgate.net/profile/Saliha_Senel/publication/230863775_The_socioeconomic_and_biologica 1_risk_factors_for_developmental_delay_in_early_childhood/links/54dfb21f0cf29666378be502.pdf

19. Aridiyah et at. 2015. The factors affecting stunting on toddlers in rural and urban areas. e-Journal of Health Library. 3(1). 163-170.

20. Bove I, Miranda T, Campoy C, Uauy R. Napol M. Stunting, overweight and child development go hand as key problems of early infancy: Uruguayan case. Early Human Development-03639(5) Elsevier. 2012. Available from: https://www.sciencedirect.com/science/article/pii/S0378378212000965

21. Perkins J,Rockli K, Krishna A, McGovern, Aguayo VM, Subramanian SV. Understanding the asoociation between stunting and shild development in low-and middle income countries: next steps for research and intervention. Social $\begin{array}{lllll}\text { Science } & \text { and } & \text { Medicine, 193, Available } & \text { from: }\end{array}$ https://pureadmin.qub.ac.uk/ws/portalfiles/portal/136420753/Stunting_SSM.pdf 